\title{
Development of the Satisfaction with Inhaled Asthma Treatment Questionnaire
}

\author{
J.L. Campbell*, G.M. Kiebert", M.R. Partridge
}

Development of the Satisfaction with Inhaled Asthma Treatment Questionnaire. J.L. Campbell, G. M. Kiebert, M.R. Partridge. (C) ERS Journals Ltd 2003.

ABSTRACT: For the management of a condition such as asthma, patients should feel confident with their medication, feel that the treatment is adequate in controlling symptoms and that side-effects of the treatment are minimal.

As no comprehensive instrument to measure patient satisfaction with inhaled asthma medication existed, the Satisfaction with Asthma Treatment Questionnaire was developed. The procedures that were used are described, and the initial validation and reliability tests are reported. The study involved focus group meetings, development, testing and modification of a preliminary instrument, and testing of the revised instrument using different samples of patients with asthma.

Factor analysis of the 26-item questionnaire identified four domains reflecting four aspects of satisfaction: effectiveness of treatment, ease of use, medication burden, and side-effects and worries. Cronbach's alpha showed evidence of internal consistency reliability. Test/retest reliability ranged from $0.66-0.74$. Interscale correlations were moderate-to-high. Significant correlations were found between domain and overall scale scores and patients' overall level of satisfaction.

The Satisfaction with Asthma Treatment Questionnaire is potentially a useful instrument for gaining insight into patient satisfaction with inhaled treatment for asthma.

Eur Respir J 2003; 22: 127-134.
*Peninsula Medical School, Exeter, and

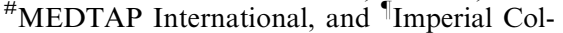
lege of Science, Technology and Medicine, National Heart and Lung Institute Division, Charing Cross Hospital, London, UK.

Correspondence: J.L. Campbell, Peninsula Medical School, Exeter, EX2 5DW, UK. Fax: 441392432223

E-mail: john.campbell@pms.ac.uk

Keywords: Clinical data

drug administration

patient reports

respiratory

survey

Received: October 242002

Accepted after revision: February 212003

Research and development was financially supported by AstraZeneca, Lund, Sweden.
For many patients, asthma is a long-term condition requiring prolonged treatment. It is important that patients feel confident with the medication they are using, that the treatment is adequate in controlling symptoms and that sideeffects of treatment are minimal and well tolerated [1]. If these conditions are not met, it is likely that patients will not comply with the prescribed treatment regimen. In turn, this noncompliance can have a negative impact on the effectiveness of treatment, and may lead to increased morbidity [2, 3] and even mortality [4].

Improving compliance in asthma may involve simplification of the treatment regimen. To assess the potential benefit in terms of compliance enhancement, it is important to know how patients feel about treatment regimens actually adopted. Such information may assist the definition of optimal medical care for the individual patient. Although the past two decades have witnessed increasing interest in the issue of patient satisfaction with treatments $[5,6]$, more work has involved patient satisfaction with the structures and processes of medical care. There appears to be a consensus that patient satisfaction is an important measure that should be included in healthcare evaluations [6, 7]. Although certain information can be derived from the medical care-satisfaction literature, studies are often too broadly focused to be of value in the assessment of satisfaction with specific regimens or therapies.

An initial literature review (1990-2000) focused on studies investigating treatment satisfaction and preferences and compliance with asthma medication. The few studies that were identified focused on the patients' satisfaction with the physical characteristics of inhalers and their preferences for various presentations of inhaled drugs (such as dry powder versus aerosol) [8-13] or dosing regimens [14].

In a cross-sectional survey of primary-care patients, BALSBAUGH et al. [15] investigated what features of asthma medications were of importance to patients. Avoidance of blood-test monitoring was the strongest of any attribute. Patients' views were also highly affected by the frequency of dosing, but not by the route of drug administration.

While several instruments exist that are useful in assessing quality of life [16], the presence of symptoms [17] or subject self-efficacy [18] in asthma, the authors were not able to identify an existing comprehensive instrument to measure patient satisfaction with inhaled asthma medication that would be suitable as an outcome measure in the context of a clinical trial. The authors concluded that it was necessary to develop such an instrument themselves, and here they report on the development and initial validation and reliability testing of the Satisfaction with Asthma Treatment Questionnaire (SATQ). Further work is planned examining the performance of the instrument in clinical settings. The study was conducted in two different centres in London, UK. The approval of the local research ethics committee was obtained for this study.

\section{Methods}

\section{Focus group meetings}

Two focus groups (afternoon, evening) were held with the aim of gaining an understanding of patients' perception of 
their treatment regimens and problems patients encounter using asthma medication and exploring patients' perspectives about the desirability of simplified treatment regimes. Inclusion criteria were: aged 18-75 yrs and diagnosis of mild, moderate or severe asthma, either well controlled or uncontrolled (as classified by their supervising general practitioner on the basis of recent peak flow records, admissions, use of treatment and personal knowledge of patient). Non-lifethreatening comorbidity was acceptable. Suitable patients were identified from primary-care clinical databases and approached by letter and telephone. Both group meetings were conducted by the same moderator and followed a similar structure.

\section{Preliminary instrument}

The preliminary instrument was based on the findings from existing literature and the focus groups and from expert opinion. Predefined basic requirements were that the written format should be suitable for self-completion by the patient, and that it should be simple, brief, and easy to understand and administer. The preliminary instrument was tested in two samples of patients familiar with the use of asthma inhalers in order to assess the comprehensiveness, comprehensibility and relevance of items. Over a period of 2 weeks, those with asthma attending either a hospital- or primary care-based chest clinic were asked to complete the questionnaire whilst waiting to be seen. The preliminary instrument was modified to reflect patients' responses.

\section{Psychometric testing}

The validity, reliability and responsiveness of the revised instrument were tested in a larger group of patients with varying severity of asthma, all of whom were familiar with the use of asthma inhalers. Patients were identified and recruited from the patient databases in the same two centres as for the pilot test. Eligibility criteria were the same as for the focus group. Additional criteria included the use of a minimum of two asthma inhalers and capability of reading and understanding English at a level allowing them to complete the questionnaire. A questionnaire and prepaid response envelope were mailed to all of these patients and a reminder was sent to nonresponders after 2 weeks. Patients who agreed to complete the questionnaire again were sent the same instrument by mail $\sim 2$ weeks after the first questionnaire.

The questionnaire incorporated additional questions relating to age, sex, employment status, time since diagnosis of asthma and the inhalers currently used, and a number of debriefing questions enquiring about the time required for completion, the degree of difficulty of questions, clarity of formulation and appropriateness and comprehensiveness of the items. The retest questionnaire also incorporated a question asking the patient's perception of change of asthma status since first completion.

\section{Data analysis}

Data from the preliminary and revised questionnaires were analysed using descriptive statistics to verify that there was variability of response categories to each question and to verify the number of missing data for each item. Tabulation of patient characteristics, as well as missing data and consistency checks were performed. Scores of the negatively phrased items were reversed, so that for all items a higher score indicated greater satisfaction. All items that were subject to a ceiling effect were eliminated.
Factor analysis (principal components with varimax rotation) assessed the data for evidence of a domain structure consistent with domains considered part of the satisfaction construct. Domain scores were constructed by summing the intrascale item ratings and dividing this by the number of items in the domain. An overall score was calculated by adding the scores of each item and dividing this by the number of items. It was not the authors' intention to explore the detailed performance of the instrument among asthma population subgroups, but to describe overall performance in samples of subjects drawn from clinical practice.

Internal consistency reliability was measured using Cronbach's alpha [19]. Test/retest reliability (reproducibility [20]) was assessed using intraclass correlation coefficients. Paired t-tests were used to compare the scores of first and second assessments from patients who completed the questionnaire twice and who had indicated no change in their asthma condition since completion of the first questionnaire. Paired samples t-tests were conducted for the individual items as well as the four factors and the global satisfaction item to test that the average of differences between both assessments differed from zero.

Construct validity was evaluated by examining Spearman's rank correlation coefficient between items and domains and between domain and overall scale scores and a global evaluation of patient satisfaction with medication. Results of the factor analysis were also used as an indicator of the construct validity of the measure. For the measures of construct validity (factor analysis and correlation coefficients) and internal consistency reliability, data from the first $(n=131)$ and second $(n=59)$ assessments were pooled (combined $n=190)$.

\section{Results}

\section{Focus groups and preliminary questionnaire}

Of 30 patients contacted by phone, 19 agreed to attend the focus group meetings. Of the 11 patients that declined, seven were unable to attend at the scheduled times. Seventeen patients (10 male) eventually attended the focus group meetings. The majority of patients had either mild or moderate controlled asthma, with only two severe cases participating in the study. Time since diagnosis of asthma varied from 3-52 yrs.

The general pattern that emerged from the focus groups was that patients had enough knowledge of their medication to allow its proper use and that the majority of patients reported having set times of the day at which they took their prescribed medication. Most patients said that they tended to adhere to the dose of maintenance medication prescribed. However, among the most experienced users there was a consensus that they had enough knowledge and experience to vary the dose of maintenance medication according to their individual needs, decreasing the dose when they were feeling stable and well, increasing the dose when they were feeling worse or susceptible to attacks.

With respect to rescue medication, patients expressed that they disliked using this medication and tried to avoid it, because they believed it to be harmful in large doses and/or "addictive". Patients were asked about ease of use and convenience and the importance of having the appropriate inhaler available at the right time. The majority of patients reported that they rarely left home without taking rescue medication with them, even for short-term activities, such as going to local shops or to the cinema. A common fear was that inhalers may run out unexpectedly. Inhalers with an indicator showing the number of remaining doses were thought to be very convenient and were preferred by patients. 
With regards to patients' preference for a specific type of inhaler, many patients had experience of different types of inhaler. For those who had, there was no consensus on the preferred type. Undesirable features of inhalers were reported to be a risk of side-effects, such as bad taste, dry throat and hoarseness.

\section{Pilot testing}

The preliminary questionnaire comprised 12 items focusing on convenience and ease of use for each inhaler used, effectiveness and potential side-effects, and patients' confidence in and satisfaction with inhalers. Two additional questions related to the degree of difficulty and comprehensiveness of the questionnaire.

Forty-seven patients (40\% male, $60 \%$ female, average age 56 yrs (range 25-78 yrs) who had asthma for an average of 17 yrs (range 1-60 yrs)) completed this questionnaire. This pretesting phase revealed a number of problems with the construction of the questionnaire. Although the majority of patients indicated that the questions were easy to answer $(65 \%)$ or at an average level of difficulty $(33 \%)$, the amount of missing data was substantial. The instruction to answer the questions separately for each inhaler used was not understood by one-half of the sample. This problem, as well as other comments from patients, led to significant revision of the instrument. All questions were changed into a statement mode, with response categories for all items revised into a 7-point scale ( 1 "strongly disagree" to 7 "strongly agree"). A number of items were added, based on the feedback received from the patients, to make the questionnaire more comprehensive. To minimise the chance of acquiesce bias, some statements were phrased positively and others negatively in a random order. For the formatting of the questionnaire, design principles were applied as outlined by MULLIN et al. [21]. The revised SATQ consisted of 35 items.

\section{Psychometric testing}

A total of 131 patients with asthma participated in the psychometric evaluation of the revised instrument representing a response rate of $60 \%$ (219 were approached to participate), a response rate in line with similar postal surveys in primary care $[22,23]$. The demographic and other patient characteristics of responders are shown in Appendix 1, table 4. Responders were of a similar sex distribution but older than nonresponders (females $68 \%$ response, males $57 \%, \mathrm{p}>0.05$; responders (mean \pm SEM) $45.4 \pm 1.3$ yrs versus nonresponders $36.5 \pm 1.6$ yrs, $\mathrm{p}<0.001 ; 54 \%$ were in employment). Of those who were unemployed, $10 \%$ indicated that their unemployment was related to their asthma. The average age was 45 yrs (range 18-70 yrs) and the majority of respondents (91\%) had been using asthma inhalers for $>1$ yr. After 2 weeks, $95(73 \%)$ patients indicated a willingness to fill out the questionnaire again, and $59(62 \%)$ retest questionnaires were completed and
Table 1. - Internal consistency and test/retest reliability

\begin{tabular}{lccc}
\hline SATQ Domain & $\begin{array}{c}\text { Items } \\
\mathrm{n}\end{array}$ & $\begin{array}{c}\text { Cronbach's } \\
\text { alpha }\end{array}$ & $\begin{array}{c}\text { Intraclass } \\
\text { correlation }\end{array}$ \\
\hline Effectiveness & 8 & 0.88 & 0.72 \\
$\begin{array}{l}\text { Ease of use } \\
\text { Burden of asthma }\end{array}$ & 7 & 0.82 & 0.66 \\
$\quad 6$ & 0.71 & 0.70 \\
$\begin{array}{l}\text { Side-effection } \\
\quad \text { and worries }\end{array}$ & 5 & 0.71 & 0.74 \\
\hline
\end{tabular}

SATQ: Satisfaction with Asthma Treatment Questionnaire.

returned. The 35-item questionnaire showed few missing data: 59 of a potential total of 6,650 responses $(0.9 \%)$.

\section{Construct validity}

Factor analysis was performed on the first 34 items in the questionnaire. The last item measures the overall satisfaction and was excluded from the factor analysis. Principal component analysis used for initial factor extraction followed by varimax rotation showed nine factors with an eigenvalue $>1$. The screen plot indicated that more than four factors added little to the variance explained and was therefore considered unwarranted. The four-factor solution accounted for $48.3 \%$ of the variance (in order 16.9, 14.4, 8.9 and 8.1\%). Item factor loadings for the varimax-rotated solution are shown in Appendix 1, table 5. Eight items showed factor loadings of $<0.35$ on any factor or had high factor loadings on more than one factor and were excluded. The final version of the questionnaire (Appendix 2) thus consisted of 26 items.

The items loading on the first factor $(\mathrm{k}=8)$ reflected contents relating to the effectiveness of asthma medication. Items loading on the second factor $(\mathrm{k}=7)$ related to ease of use of asthma inhalers and treatment compliance. The third factor $(\mathrm{k}=6)$ related to the burden of asthma medication in general and inhalers in particular. The items loading on the fourth factor $(k=5)$ related to potential side-effects and worries about taking the right amount of medication.

\section{Internal consistency and test/retest reliability}

The results of the internal consistency and test/retest reliability analyses are presented in table 1. Cronbach's alpha values ranged $0.71-0.88$ (exceeding the 0.70 criterion proposed in the literature [24, 25]) for the four scales, indicating evidence of reliability of the scales and no redundancy of the items. Intraclass correlation coefficients were used as a measure of test/retest reliability (reproducibility). The four scales ranged 0.66-0.74. Paired samples t-tests for the individual items, as well as the four factors and the global satisfaction item, showed no significant differences for any of the comparisons (data not shown).

Table 2. - Satisfaction with Asthma Treatment Questionnaire distribution properties

\begin{tabular}{|c|c|c|c|c|c|c|}
\hline & Effectiveness & Ease of use & Burden of asthma medication & Side-effects and worries & Overall score & Global satisfaction \\
\hline Mean & 5.62 & 5.90 & 4.98 & 4.68 & 5.30 & 5.84 \\
\hline SD & 1.12 & 1.11 & 1.34 & 1.39 & 0.88 & 1.42 \\
\hline SE & 0.08 & 0.08 & 0.10 & 0.10 & 0.07 & 0.10 \\
\hline Min.-Max. & $2.38-7.0$ & $1.71-7.0$ & $1.17-7.0$ & $1.40-7.0$ & $2.61-7.0$ & $1.0-7.0$ \\
\hline Ceiling \% & 15 & 16 & 8 & 4 & 1 & 47 \\
\hline
\end{tabular}

Min.: minimum; Max.: maximum. 
Table 3. - Correlations between scales comprising the Satisfaction with Asthma Treatment Questionnaire (SATQ), and between the SATQ and a global satisfaction rating (Spearman's rho correlations)

\begin{tabular}{|c|c|c|c|c|}
\hline & Ease of use & $\begin{array}{c}\text { Burden of } \\
\text { asthma medication }\end{array}$ & $\begin{array}{l}\text { Side-effects } \\
\text { and worries }\end{array}$ & $\begin{array}{c}\text { Global } \\
\text { satisfaction }\end{array}$ \\
\hline Effectiveness & 0.55 & 0.40 & 0.29 & 0.70 \\
\hline Ease of use/treatment compliance & & 0.41 & 0.18 & 0.44 \\
\hline Burden of asthma medication & & & 0.32 & 0.39 \\
\hline Side-effects and worries & & & & 0.39 \\
\hline
\end{tabular}

Table 2 shows the distribution of the four scales, the overall score (average of the four domain scores) and the global satisfaction item. Although the percentage of patients that reported the highest possible score (per cent ceiling) was relatively small, the majority of patients were at the upper end of the distribution, indicating good satisfaction with the management of their asthma. There was no difference between patient groups defined by age or sex with respect to average scores (males 5.41 versus females 5.30, nonsignificant (NS); $<45$ yrs 5.31 versus $>45$ yrs 5.36, NS). Patients in this study were generally satisfied with their medication; mean domain score values indicate they were most satisfied with the effectiveness and ease of use of their medication and least satisfied with medication burden and side-effects and worries. Patients also reported high satisfaction scores on the global item, with nearly one-half of the patients reporting the highest possible score.

Spearman's rank correlation coefficients between domains are shown in table 3. Significant correlations were found between domain and overall scale scores and patients' global satisfaction with their medication. The strongest relationship was between satisfaction with effectiveness and global satisfaction. The lowest correlation was between the domain measuring ease of use and with side-effects/worries about medication.

\section{Patient evaluation of measure}

Patient responses to questions concerning the degree of difficulty and comprehensiveness of the instrument are shown in Appendix 1, table 6. The majority of patients did not experience any problems with the difficulty or phrasing of the items. Twenty-seven patients provided feedback regarding the formulation of questions (Appendix 1) resulting in the removal of one question from the questionnaire. No aspects of patients' satisfaction already addressed in the SATQ were identified. Most $(60 \%)$ of the patients estimated their completion time for the questionnaire to be $<7 \mathrm{~min}$.

\section{Discussion}

The purpose of this study was to describe the development and psychometric properties of an instrument evaluating satisfaction with asthma treatment for patients using inhaled medication. A multistep approach was taken, involving review of the literature, patient focus groups, pilot testing of the preliminary instrument and psychometric testing of the revised instrument, all in a different population of patients with asthma. In line with previous qualitative work [26], the focus groups identified a range of views held among subjects regarding the nature and management of asthma. The results of the present study suggest scores on items, comprising the domains and overall scale, are internally consistent indicating relatively little measurement error. Test/retest results indicate that scores are reproducible over time, which is also an indication of measurement precision. The SATQ is a brief, easy to use, patient-completed instrument.
The questionnaire can now be used in a wider variety of clinical settings and further validation of the discriminatory power and the sensitivity of the instrument can be undertaken, for example, against objective measures of lung function. The performance of the questionnaire also needs to be compared with the performance of other instruments measuring similar constructs and against other measurement of asthma care (e.g. treatment compliance), and among subgroups of asthma patients defined by degree of disease control and sociodemographic profile.

Among the patients included in this study, generally there was high satisfaction with their asthma treatment. This is in line with another recent, larger UK survey [27] of patients with asthma who had seen their general practitioner in the past 3 yrs; $56 \%$ were very satisfied and a further $31 \%$ were fairly satisfied with primary care, and $85.3 \%$ stated that their asthma was well controlled or completely controlled. The majority of patients in this study had had asthma for a long period of time and were accustomed to asthma medication in general and to the use of inhalers in particular. Apart from adequate disease management and appropriate medication use, it is likely that the patients' adaptation to the illness and familiarity with the appropriate use of medication all contribute to a greater level of satisfaction. As the formulation and delivery of new asthma treatments becomes more sophisticated, it is important to have robust instruments with known psychometric properties available for the routine evaluation of new therapies. The authors believe the Satisfaction with Asthma Treatment Questionnaire may fill that role.

\section{Appendix 1}

Table 4. - Psychometric evaluation: sample demographic and clinical characteristics

Characteristics

\begin{tabular}{lc}
\hline Mean age (range) yrs & $45(18-70)$ \\
Female & $86(66)$ \\
Male & $45(34)$ \\
Employment status & \\
Employed full-time & $57(44)$ \\
Employed part-time & $13(10)$ \\
Unemployed & $57(44)$ \\
Missing & $4(3)$ \\
Duration of using asthma inhalers & \\
3-6 months & $3(2)$ \\
$7-12$ months & $5(4)$ \\
$1-3$ yrs & $22(17)$ \\
$4-6$ yrs & $21(16)$ \\
$>6$ yrs & $76(58)$ \\
Missing & $4(3)$ \\
\hline
\end{tabular}

Data are expressed as n (\%) unless otherwise stated. Percentages may not add up to 100 due to rounding. 
Table 5. - Item loadings $>0.35$ for varimax-rotated solution with four principal components

\begin{tabular}{|c|c|}
\hline Factor & Loadi \\
\hline \multicolumn{2}{|l|}{ Factor 1: Effectiveness } \\
\hline $\begin{array}{l}\text { My inhaler(s) help(s) me feel in control of my } \\
\text { asthma symptoms }\end{array}$ & 0.72 \\
\hline My asthma medication gives me relief that lasts & 0.80 \\
\hline I feel in control of my disease & 0.69 \\
\hline $\begin{array}{l}\text { When I take my medication, I feel confident } \\
\text { that my asthma symptoms will be controlled }\end{array}$ & 0.80 \\
\hline My asthma medication is very effective & 0.76 \\
\hline $\begin{array}{l}\text { My asthma medication gives me the confidence } \\
\text { I need to get through the day }\end{array}$ & 0.59 \\
\hline $\begin{array}{l}\text { I would feel happy to continue my current asthma } \\
\text { medication }\end{array}$ & 0.59 \\
\hline $\begin{array}{l}\text { I would recommend my inhaler(s) to other people } \\
\text { with asthma }\end{array}$ & 0.60 \\
\hline \multicolumn{2}{|l|}{ Factor 2: Ease of use } \\
\hline Keeping track of my asthma medication is easy & 0.66 \\
\hline $\begin{array}{l}\text { I always have the right asthma inhaler with me } \\
\text { when needed }\end{array}$ & 0.80 \\
\hline It is easy to find the right inhaler when I need it & 0.70 \\
\hline $\begin{array}{l}\text { I rarely leave home without taking my inhaler(s) } \\
\text { with me }\end{array}$ & 0.69 \\
\hline $\begin{array}{l}\text { It is easy to remember to take my asthma } \\
\text { medication }\end{array}$ & 0.62 \\
\hline I feel confident in using my inhaler(s) & 0.64 \\
\hline $\begin{array}{l}\text { It is easy to fit my asthma medication into my } \\
\text { everyday life }\end{array}$ & 0.60 \\
\hline \multicolumn{2}{|l|}{ Factor 3: Burden of asthma medication } \\
\hline $\begin{array}{l}\text { My asthma inhaler(s) fits easily in my purse or } \\
\text { pocket }\end{array}$ & 0.49 \\
\hline $\begin{array}{l}\text { Carrying my asthma inhaler(s) can be cumbersome } \\
\text { (e.g. size/weight) }\end{array}$ & 0.66 \\
\hline I wish my asthma medication was easier to take & 0.65 \\
\hline I sometimes leave home with the wrong inhaler & 0.47 \\
\hline $\begin{array}{l}\text { Using more than one inhaler can be a hassle or a } \\
\text { problem }\end{array}$ & 0.67 \\
\hline $\begin{array}{l}\text { Using my asthma inhaler(s) in public is } \\
\text { embarrassing }\end{array}$ & 0.57 \\
\hline \multicolumn{2}{|l|}{ Factor 4: Side-effects and worries } \\
\hline My asthma medication makes my throat dry & 0.74 \\
\hline $\begin{array}{l}\text { My asthma medication leaves a bad taste in my } \\
\text { mouth }\end{array}$ & 0.68 \\
\hline My asthma medication affects my voice & 0.72 \\
\hline $\begin{array}{l}\text { I worry that my inhaler is not giving me enough } \\
\text { medication }\end{array}$ & 0.47 \\
\hline $\begin{array}{l}\text { I worry that I am not taking the right medication } \\
\text { for my symptoms }\end{array}$ & 0.42 \\
\hline
\end{tabular}

Each item was scored on a scale of 1-7, where higher scores indicated greater satisfaction; responses on negatively worded items were reversed before domain scores were computed.

\section{Patient evaluation of measure}

Twenty-seven patients provided feedback regarding the formulation of questions. Some comments referred to general issues such as "I would be happy not to have asthma" in response to the item "I would feel happy to continue my current asthma medication" or "I recommend they see their doctor" in response to those who reported difficulties with the ease of inhaler use. Of the three patients who reported they
Table 6. - Degree of difficulty and comprehensiveness of the instrument

\begin{tabular}{lcc}
\hline & $\begin{array}{c}\text { First } \\
\text { assessment }\end{array}$ & $\begin{array}{r}\text { Retest } \\
\text { sample }\end{array}$ \\
\hline $\begin{array}{l}\text { Subjects n } \\
\text { How difficult were the }\end{array}$ & 131 & 59 \\
questions to answer? & & \\
$\quad$ Very difficult & 0 & 0 \\
Difficult & $5(4)$ & 0 \\
Not difficult/not easy & $35(27)$ & $20(34)$ \\
Easy & $57(44)$ & $19(32)$ \\
Very easy & $32(24)$ & $20(34)$ \\
Missing & $2(1)$ & 0
\end{tabular}

Were there any questions that

were not clearly formulated?

$$
\text { No } 108(82)
$$

Yes $20(15)$

$49(83)$

Missing

$10(17)$

Were there any questions that you found upsetting?

$\mathrm{No}$

3 (2)

Yes

Missing

Do you feel that certain important

$3(2)$

questions about your asthma medication are missing?

$\begin{array}{lcc}\text { No } & 96(73) & 44(76) \\ \text { Yes } & 32(24) & 13(22) \\ \text { Missing } & 3(2) & 1(2)\end{array}$

Approximately, how long did it

take you to fill out the

ASTHMA questionnaire?

$\begin{array}{lcc}1-3 \mathrm{~min} & 29(22) & 17(29) \\ 4-6 \mathrm{~min} & 50(38) & 27(46) \\ 7-9 \mathrm{~min} & 30(23) & 7(12) \\ 10-15 \mathrm{~min} & 14(11) & 8 \\ >15 \mathrm{~min} & 6(5) & 7(12) \\ \text { Missing } & 2(1) & 1(2)\end{array}$

Compared with the last time that

you filled out this questionnaire, do you think your asthma

condition has changed?

Improved very much

Improved a bit

Remained the same

Deteriorated a bit

Deteriorated very much

Data are presented as $\mathrm{n}(\%)$ unless otherwise stated.

found some questions upsetting, two referred to the item "I am concerned that the amount of medicines I am taking is/will be harmful or addictive". One patient was afraid that this could lead to discontinuation of treatment and one patient found this question provoking "because I haven't questioned my medication for years". This question was removed in the factor analysis as the item loaded high on three factors. Although 52 patients indicated that aspects of asthma medication had not been addressed in the questionnaire, the majority of their suggestions referred to aspects that the authors were not attempting to assess, such as the impact of asthma on patients' lives, seasonal influences or the use of other medication. 


\section{Appendix 2: Satisfaction with Asthma Treatment Questionnaire final version}

This questionnaire asks for your opinions about your current asthma medication. This information will help us to know how you feel about your current medication and how effective it is in controlling your asthma symptoms.
The questionnaire contains 26 questions. Please read and answer all the questions by circling the number that best reflects your opinion today.

For example: circling the figure 7 below means that you strongly agree with the statement: "My asthma medication provides fast relief of my asthma symptoms".

My asthma medication provides fast relief of my asthma symptoms.

\section{Strongly}

disagree
1 .

.............

3 4.

. .5

Strongly

agree

Please read and answer all the questions by circling the number that best reflects your opinion today.

\begin{tabular}{|c|c|}
\hline 1. Keeping track of my asthma medication is easy. & $\begin{array}{l}\begin{array}{l}\text { Strongly } \\
\text { disagree } \\
1 \ldots \ldots \ldots 2 \ldots \ldots \ldots 3 \ldots \ldots 4 \ldots \ldots .5 \ldots \ldots 6 \ldots \ldots 7\end{array} \\
\begin{array}{c}\text { Strongly } \\
\text { agree }\end{array}\end{array}$ \\
\hline 2. I always have the right asthma inhaler with me when needed. & $\begin{array}{l}\begin{array}{l}\text { Strongly } \\
\text { disagree } \\
1 \ldots \ldots \ldots 2 \ldots \ldots \ldots 3 \ldots \ldots .4 \ldots \ldots .5 \ldots \ldots 6 \ldots \ldots .7\end{array} \\
\begin{array}{c}\text { Strongly } \\
\text { agree }\end{array}\end{array}$ \\
\hline $\begin{array}{l}\text { 3. Carrying my asthma inhaler(s) can be cumbersome } \\
\text { (e.g. size/weight). }\end{array}$ & $\begin{array}{l}\begin{array}{l}\text { Strongly } \\
\text { disagree } \\
1 \ldots \ldots \ldots 2 \ldots \ldots \ldots 3 \ldots \ldots 4 \ldots \ldots .5 \ldots \ldots 6 \ldots \ldots 7\end{array} \\
\begin{array}{c}\text { Strongly } \\
\text { agree }\end{array}\end{array}$ \\
\hline 4. It is easy to find the right inhaler when I need it. & $\begin{array}{l}\begin{array}{l}\text { Strongly } \\
\text { disagree } \\
1 \ldots \ldots \ldots 2 \ldots \ldots \ldots 3 \ldots \ldots 4 \ldots \ldots .5 \ldots \ldots 6 \ldots \ldots 7\end{array} \\
\begin{array}{c}\text { Strongly } \\
\text { agree }\end{array}\end{array}$ \\
\hline 5. My inhaler(s) helps me feel in control of my asthma symptoms. & $\begin{array}{l}\begin{array}{l}\text { Strongly } \\
\text { disagree } \\
1 \ldots \ldots \ldots 2 \ldots \ldots \ldots 3 \ldots \ldots 4 \ldots \ldots .5 \ldots \ldots 6 \ldots \ldots 7\end{array} \\
\begin{array}{c}\text { Strongly } \\
\text { agree }\end{array}\end{array}$ \\
\hline $\begin{array}{l}\text { 6. I worry that I am not taking the right medication for my } \\
\text { symptoms. }\end{array}$ & $\begin{array}{l}\begin{array}{l}\text { Strongly } \\
\text { disagree } \\
1 \ldots \ldots \ldots 2 \ldots \ldots \ldots 3 \ldots \ldots 4 \ldots \ldots .5 \ldots \ldots 6 \ldots \ldots 7\end{array} \\
\begin{array}{c}\text { Strongly } \\
\text { agree }\end{array}\end{array}$ \\
\hline 7. I feel in control of my disease. & 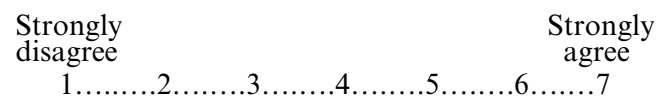 \\
\hline 8. It is easy to fit my asthma medication into my everyday life. & $\begin{array}{l}\begin{array}{l}\text { Strongly } \\
\text { disagree } \\
1 \ldots \ldots \ldots .2 \ldots \ldots \ldots 3 \ldots \ldots 4 \ldots \ldots .5 \ldots \ldots 6 \ldots \ldots 7\end{array} \\
\begin{array}{c}\text { Strongly } \\
\text { agree }\end{array}\end{array}$ \\
\hline 9. Using my asthma inhaler(s) in public is embarrassing. & $\begin{array}{l}\begin{array}{l}\text { Strongly } \\
\text { disagree } \\
1 \ldots \ldots \ldots 2 \ldots \ldots \ldots 3 \ldots \ldots 4 \ldots \ldots .5 \ldots \ldots 6 \ldots \ldots 7\end{array} \\
\begin{array}{c}\text { Strongly } \\
\text { agree }\end{array}\end{array}$ \\
\hline 10. I rarely leave home without taking my inhaler(s) with me. & $\begin{array}{l}\begin{array}{l}\text { Strongly } \\
\text { disagree } \\
1 \ldots \ldots \ldots 2 \ldots \ldots \ldots 3 \ldots \ldots 4 \ldots \ldots .5 \ldots \ldots 6 \ldots \ldots\end{array} \\
\begin{array}{c}\text { Strongly } \\
\text { agree }\end{array}\end{array}$ \\
\hline 11. My asthma medication makes my throat dry. & $\begin{array}{l}\begin{array}{l}\text { Strongly } \\
\text { disagree } \\
1 \ldots \ldots \ldots 2 \ldots \ldots \ldots 3 \ldots \ldots 4 \ldots \ldots .5 \ldots \ldots 6 \ldots \ldots 7\end{array} \\
\begin{array}{c}\text { Strongly } \\
\text { agree }\end{array}\end{array}$ \\
\hline
\end{tabular}




\begin{tabular}{|c|c|}
\hline 12. I would feel happy to continue my current asthma medication. & $\begin{array}{l}\begin{array}{l}\text { Strongly } \\
\text { disagree } \\
1 \ldots \ldots \ldots 2 \ldots \ldots \ldots 3 \ldots \ldots 4 \ldots \ldots \ldots 5 \ldots \ldots 6 \ldots \ldots\end{array} \\
\begin{array}{c}\text { Strongly } \\
\text { agree }\end{array}\end{array}$ \\
\hline $\begin{array}{l}\text { 13. When I take my medication, I feel confident that my asthma } \\
\text { symptoms will be controlled. }\end{array}$ & $\begin{array}{l}\begin{array}{l}\text { Strongly } \\
\text { disagree } \\
1 \ldots \ldots \ldots .2 \ldots \ldots \ldots 3 \ldots \ldots .4 \ldots \ldots .5 \ldots \ldots 6 \ldots \ldots .7\end{array} \\
\begin{array}{c}\text { Strongly } \\
\text { agree }\end{array}\end{array}$ \\
\hline 14. My asthma medication leaves a bad taste in my mouth. & $\begin{array}{l}\begin{array}{l}\text { Strongly } \\
\text { disagree } \\
1 \ldots \ldots \ldots .2 \ldots \ldots \ldots 3 \ldots \ldots .4 \ldots \ldots .5 \ldots \ldots .6 \ldots \ldots 7\end{array} \\
\begin{array}{c}\text { Strongly } \\
\text { agree }\end{array}\end{array}$ \\
\hline 15. My asthma inhaler(s) fits easily in my purse or pocket. & $\begin{array}{cc}\begin{array}{l}\text { Strongly } \\
\text { disagree }\end{array} & \begin{array}{c}\text { Strongly } \\
\text { agree }\end{array} \\
1 \ldots \ldots \ldots 2 \ldots \ldots \ldots 3 \ldots \ldots 4 \ldots \ldots . . \ldots \ldots \ldots 6 \ldots .7\end{array}$ \\
\hline 16. It is easy to remember to take my asthma medication. & $\begin{array}{cc}\begin{array}{l}\text { Strongly } \\
\text { disagree }\end{array} & \begin{array}{c}\text { Strongly } \\
\text { agree }\end{array} \\
1 \ldots \ldots \ldots 2 \ldots \ldots \ldots 3 \ldots \ldots . \ldots \ldots \ldots 5 \ldots \ldots 6 \ldots \ldots 7\end{array}$ \\
\hline 17. I sometimes leave home with the wrong inhaler. & $\begin{array}{c}\begin{array}{l}\text { Strongly } \\
\text { disagree }\end{array} \\
1 \ldots \ldots \ldots 2 \ldots \ldots . . \ldots \ldots .4 \ldots \ldots . \ldots \ldots \ldots 6 \ldots \ldots\end{array}$ \\
\hline 18. My asthma medication affects my voice. & $\begin{array}{l}\begin{array}{l}\text { Strongly } \\
\text { disagree } \\
1 \ldots \ldots \ldots 2 \ldots \ldots \ldots 3 \ldots \ldots .4 \ldots \ldots .5 \ldots \ldots 6 \ldots \ldots .7\end{array} \\
\begin{array}{c}\text { Strongly } \\
\text { agree }\end{array}\end{array}$ \\
\hline 19. I feel confident in using my inhaler(s). & $\begin{array}{c}\begin{array}{l}\text { Strongly } \\
\text { disagree } \\
1 \ldots \ldots \ldots 2 \ldots \ldots \ldots 3 \ldots \ldots .4 \ldots \ldots .5 \ldots \ldots 6 \ldots \ldots .7\end{array} \\
\begin{array}{c}\text { Strongly } \\
\text { agree }\end{array}\end{array}$ \\
\hline 20. Using more than one inhaler can be a hassle or a problem. & $\begin{array}{l}\begin{array}{l}\text { Strongly } \\
\text { disagree } \\
1 \ldots \ldots \ldots 2 \ldots \ldots \ldots 3 \ldots \ldots .4 \ldots \ldots .5 \ldots \ldots 6 \ldots \ldots .7\end{array} \\
\begin{array}{c}\text { Strongly } \\
\text { agree }\end{array}\end{array}$ \\
\hline 21. I worry that my inhaler is not giving me enough medication. & $\begin{array}{l}\begin{array}{l}\text { Strongly } \\
\text { disagree } \\
1 \ldots \ldots \ldots 2 \ldots \ldots \ldots 3 \ldots \ldots .4 \ldots \ldots .5 \ldots \ldots 6 \ldots \ldots .7\end{array} \\
\begin{array}{c}\text { Strongly } \\
\text { agree }\end{array}\end{array}$ \\
\hline 22. I would recommend my inhaler(s) to other people with asthma. & $\begin{array}{l}\begin{array}{l}\text { Strongly } \\
\text { disagree } \\
1 \ldots \ldots \ldots 2 \ldots \ldots \ldots 3 \ldots \ldots .4 \ldots \ldots .5 \ldots \ldots 6 \ldots \ldots .7\end{array} \\
\begin{array}{c}\text { Strongly } \\
\text { agree }\end{array}\end{array}$ \\
\hline 23. I wish my asthma medication was easier to take. & $\begin{array}{cc}\begin{array}{l}\text { Strongly } \\
\text { disagree }\end{array} & \begin{array}{c}\text { Strongly } \\
\text { agree }\end{array} \\
1 \ldots \ldots \ldots 2 \ldots \ldots \ldots 3 \ldots \ldots 4 \ldots \ldots . \ldots \ldots \ldots 6 \ldots .7\end{array}$ \\
\hline 24. My asthma medication gives me relief that lasts. & $\begin{array}{c}\begin{array}{l}\text { Strongly } \\
\text { disagree }\end{array} \\
1 \ldots \ldots \ldots 2 \ldots \ldots . \ldots \ldots \ldots 4 \ldots \ldots . \ldots \ldots \ldots \ldots \ldots\end{array}$ \\
\hline 25. My asthma medication is very effective. & $\begin{array}{cc}\begin{array}{l}\text { Strongly } \\
\text { disagree }\end{array} & \begin{array}{c}\text { Strongly } \\
\text { agree }\end{array} \\
1 \ldots \ldots \ldots 2 \ldots \ldots \ldots 3 \ldots \ldots 4 \ldots \ldots . \ldots \ldots \ldots 6 \ldots \ldots 7\end{array}$ \\
\hline $\begin{array}{l}\text { 26. My asthma medication gives me the confidence I need to } \\
\text { get through the day. }\end{array}$ & $\begin{array}{c}\begin{array}{l}\text { Strongly } \\
\text { disagree } \\
1 \ldots \ldots \ldots 2 \ldots \ldots \ldots 3 \ldots \ldots . \ldots \ldots \ldots 5 \ldots \ldots 6 \ldots \ldots 7\end{array} \\
\begin{array}{c}\text { Strongly } \\
\text { agree }\end{array}\end{array}$ \\
\hline
\end{tabular}

\section{Thank you for answering these questions!}

Reproduced with permission from AstraZeneca R\&D, Lund, Sweden. SATQ is copyrighted. It may not be altered, sold (paper or electronic), translated or adapted from another medium without written permission of AstraZeneca R\&D, Lund, Sweden. 
Acknowledgements. The authors would like to thank N.K. Leidy (MEDTAP International), E. Ståhl, A-C. Mörk and K. Svensson (AstraZeneca, Lund, Sweden), and S. Schroter and N. Britten for their advice and assistance during the study.

\section{References}

1. Osman L. The patient perspective. What should a new anti-asthma agent provide? Drugs 1996; 52: Suppl. 6, 29-35.

2. Horn CR, Clark TJ, Cochrane GM. Compliance with inhaled therapy and morbidity from asthma. Respir Med 1990; 84: 67-70.

3. Donahue JG, Weiss ST, Livingston JM, Goetsch MA, Greineder DK, Platt R. Inhaled steroids and the risk of hospitalization for asthma. JAMA 1997; 277: 887-891.

4. Suissa S, Ernst P, Benayoun S, Baltzan M, Cai B. Low-dose inhaled corticosteroids and the prevention of death from asthma. N Engl J Med 2000; 343: 332-336.

5. Aharony L, Strasser S. Patient satisfaction: What we know about and what we still need to explore. Med Care Rev 1993; 50: 49-79.

6. Weaver M, Patrick DL, Markson LE, Martin D, Frederic I, Berger M. Issues in the measurement of satisfaction with treatment. Am J Manag Care 1997; 3: 579-594.

7. Ross CK, Steward CA, Sinacore JM. A comparative study of seven measures of patient satisfaction. Med Care 1995; 33: 392-406.

8. van der Palen J, Klein JJ, Schildkamp AM. Comparison of a new multidose powder inhaler (Diskus/Accuhaler) and the Turbuhaler regarding preference and ease of use. J Asthma 1998; 35: 147-152.

9. Pieters WR, Stallaert RA, Prins J, et al. A study on the clinical equivalence and patient preference of fluticasone propionate 250 microg twice daily via the Diskus/Accuhaler inhaler or the Diskhaler inhaler in adult asthmatic patients. J Asthma 1998; 35: 337-345.

10. Mahajan P, Okamoto L. Patient satisfaction with the Diskhaler and the Diskus inhaler, a new multidose power delivery system for the treatment of asthma. Clin Ther 1997; 19: 1126-1134.

11. Simons FE. A comparison of beclomethasone, salmeterol, and placebo in children with asthma. Beclomethasone Dipropionate-Salmeterol Xinafoate Study Group. $N$ Engl J Med 1997; 337: 1659-1665.
12. van der Palen J, Klein JJ, Kerkhoff $\mathrm{AH}$, van Herwaarden CL. Evaluation of the effectiveness of four different inhalers in patients with chronic obstructive pulmonary disease. Thorax 1995; 50: 1183-1187.

13. Boe J, Stiksa G, Svensson K, Asbrink E. New method of evaluating patient preference for different inhalation delivery systems. Ann Allergy 1992; 68: 255-260.

14. Campbell LM. Once-daily inhaled corticosteroids in mild to moderate asthma: improving acceptance of treatment. Drugs 1999; 58: 33

15. Balsbaugh TA, Chambers CV, Diamond JJ. Asthma controller medications: what do patients want? J Asthma 1999; 36: 591-596.

16. Juniper EF, Guyatt GH, Epstein RS, Ferrie PJ, Jaeschke R, Hiller TK. Evaluation of impairment of health related quality of life in asthma: development of a questionnaire for use in clinical trials. Thorax 1992; 47: 76-83.

17. Kinsman RA, Luparello T, O'Banion K, Spector S. Multidimensional analysis of the subjective symptomatology of asthma. Psychosom Med 1973; 35: 250-267.

18. Creer TL. Living with asthma: replications and extensions. Health Educ Quarterly 1987; 14: 319-331.

19. Cronbach LJ. Coefficent alpha and the internal reliability of tests. Psychometrica 1951; 16: 297-334.

20. Bravo G, Potvin L. Estimating the reliability of continuous measure using Cronbach's alpha or the intraclass correlation coefficient: toward the integration of two traditions. J Clin Epidemiol 1991; 44: 381-390.

21. Mullin PA, Lohr KN, Bresnahan BW, McNulty P. Applying cognitive design principles to formatting HRQOL instruments. Qual Life Res 2000; 9: 13-27.

22. Billinghurst $\mathrm{B}$, Whitfield $\mathrm{M}$. Why do patients change their general practitioner? A postal questionnaire study of patients in Avon. Br J Gen Pract 1993; 43: 336-338.

23. Salisbury C. Postal survey of patients' satisfaction with a general practice out of hours cooperative. BMJ 1997; 314 1594-1598.

24. Nunnally JC, Bernstein IH, eds. Psychometric Theory. 3rd Edn. New York, McGraw-Hill, 1994

25. Scientific Advisory Committee of the Medical Outcomes Trust. Instrument review criteria. Med Outcomes Trust Bulletin 1995; 3: i-iv.

26. Adams S, Pill R, Jones A. Medication, chronic illness and identity: the perspective of people with asthma. Soc Sci Med 1997; 45: 189-201.

27. Price D, Wolfe S. Delivery of asthma care; patients use and views on healthcare services, as determined from a nationwide interview survey. Asthma $J$ 2000; 5: 141-144. 